\title{
Karyotype and male pre-reductional meiosis of the sharpshooter Tapajosa rubromarginata (Hemiptera: Cicadellidae)
}

\author{
Graciela R. de Bigliardo ${ }^{1,2}$, Eduardo Gabriel Virla ${ }^{3}$, Sara Caro $^{1} \&$ Santiago Murillo Dasso ${ }^{1}$ \\ 1. Facultad de Ciencias Naturales e IML. U.N.T. Miguel Lillo 205. San Miguel de Tucumán (4000), Tucumán, \\ Argentina; grabigliardo@ hotmail.com \\ 2. Fundación Miguel Lillo. Miguel Lillo 251. San Miguel de Tucumán (4000), Tucumán, Argentina; \\ fmlbot@tucbbs.com.ar \\ 3. PROIMI-Biotechnology, Biocontrol Div. Av. Belgrano \& Pje. Caseros. San Miguel de Tucumán (4000), Tucumán, \\ Argentina; evirla@hotmail.com
}

Received 12-IV-2010. Corrected 17-IX-2010. Accepted 19-X-2010.

\begin{abstract}
Cicadellidae in one of the best represented families in the Neotropical Region, and the tribe Proconiini comprises most of the xylem-feeding insects, including the majority of the known vectors of xylem-born phytopathogenic organisms. The cytogenetics of the Proconiini remains largely unexplored. We studied males of Tapajosa rubromarginata (Signoret) collected at El Manantial (Tucumán, Argentina) on native spontaneous vegetation where Sorghum halepense predominates. Conventional cytogenetic techniques were used in order to describe the karyotype and male meiosis of this sharpshooter. T. rubromarginata has a male karyological formula of $2 \mathrm{n}=21$ and a sex chromosome system XO:XX $\left(\sigma^{7}: Q_{+}\right)$. The chromosomes do not have a primary constriction, being holokinetic and the meiosis is pre-reductional, showing similar behavior both for autosomes and sex chromosomes during anaphase I. For this stage, chromosomes are parallel to the acromatic spindle with kinetic activities in the telomeres. They segregate reductionally in the anaphase I, and towards the equator during the second division of the meiosis. This is the first contribution to cytogenetic aspects on proconines sharpshooters, particularly on this economic relevant Auchenorrhyncha species. Rev. Biol. Trop. 59 (1): 309314. Epub 2011 March 01.
\end{abstract}

Key words: Insecta, Cicadellidae, Proconiini, karyotype, holokinetic chromosomes, sex chromosomes.

Cicadellidae (Hemiptera: Auchenorhyncha) is a large family that includes approximately 22000 species, which is well represented in the Neotropical region (McKamey 2002). Due to their feeding habits and well-known capacity to transmit plant pathogens, some species represent significant pests for many economically important crops (Freytag \& Sharkey 2002).

The tribe Proconiini (Cicadellinae) is composed of 59 genera and over 400 species, all confined to the Americas (Young 1968, Rakitov \& Dietrich 2001), even though Homalodisca vitripennis (Germar) has recently invaded Pacific Islands (Grandgirard et al.
2008). The Proconiini (sharpshooters) is one of the largest groups of xylem-feeding insects and includes the majority of the known vectors of xylem-born phytopathogenic organisms (Rakitov \& Dietrich 2001, Redak et al. 2004). Tapajosa rubromarginata Signoret is distributed in tropical and subtropical areas of Brazil and Argentina (Paradell 1995, de Azevedo-Filho \& Carvallo 2004, Takiya \& Dimitriev 2008). It has been collected from 15 host plants, Avena sativa (cultivated oat), Saccharum officinalis (sugarcane), Sorghum halepense (Johnson grass), Zea mays (corn), Tritricum aestivun (wheat), Bromus unioloides 
(rescuegrass) (Poaceae), Dahlia pinnata (dahlia) (Asteraceae), Tabebuia lapacho (yellow palmer trumpettree) (Bignoniaceae), Ipomaea sp. (Concolvulaceae), Glycine max (soybean), Medicago sativa (alfalfa) (Fabaceae) Populus sp. (poplar) (Salicaceae), Lantana camara (lantana), Hibiscus sp. (Verbenaceae), and Citrus sinensis (Rutaceae) (de Azevedo-Filho \& Carvalho 2004, Remes Lenicov et al. 1998, Remes Lenicov et al. 2004, Virla et al. 2007). This species is associated with grasslands and spontaneous weeds, and looses in sugar cane and corn crops in Northwestern Argentina (Costilla et al. 1972, Remes Lenicov et al. 1998, Virla et al. 2007).

Cytogenetic studies on Auchenorrhyncha began from Boring (1907) who analyzed spermatogenesis in 22 species. Recently, some contributions have been made (Halkka 1957, 1959, 1960a,b, de Lello et al. 1982, Kuznetsova et al. 2003, 2009, Nokkala et al. 2004) but there still a noticeable lack of information for several groups. Fulgoroidea is the most studied superfamily, and the reported chromosome numbers range from $2 n=19(X O)$ to $2 n=37(X O)$ in males (Maryanska-Nadachowska et al. 2006). Most of the species have $2 \mathrm{n}=26(\mathrm{XY}), 2 \mathrm{n}=27$ (XO) or $2 n=29(X O)$, with a manifest preponderance of the latter complement (Halkka 1959, Kuznetsova et al. 1998). In Auchenorrhyncha the XO system is predominates and the $\mathrm{XY}$ system is secondary (Kuznetsova et al. 1998). Cicadellidae, like other Auchenorrhyncha, have holokinetic chromosomes, showing highly variable numbers in their karyotype. This type of chromosome plays an essential role in karyotype evolution, due to the high levels of fragmentation and fusions (Maryanska-Nadachowska et al. 2006).

Proconiini cytogenetics remains largely unexplored; in addition, this subject is totally unknown for Argentinian Auchenorrhyncha species. The aim of this contribution is to report the chromosome number in T. rubromarginata, and provide a brief description of holokinetic chromosomes behavior during male meiosis.

\section{MATERIAL AND METHODS}

Males of T. rubromarginata were obtained from a wild population inhabiting a corn agroecosystem and its surrounding vegetation composed mostly of Sorghum halepense (L.) Pers, at El Manantial, Tucumán province

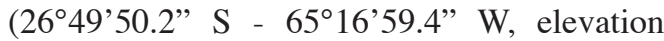
$495 \mathrm{~m})$. Individuals were sexed by external characters, and confirmed later by the morphology of their gonads. The testes, obtained form 15 individuals, were preserved in a freshlyprepared mixture of methanol/glacial acetic acid (3:1) at $2-4^{\circ} \mathrm{C}$ under dark conditions.

For the analysis of meiotic cells, the testicular follicles were processed by using the squash technique and then stained according to the conventional Feulgen method by using Schiff reactive after an acid hydrolysis with $1 \mathrm{~N} \mathrm{HCL}$ (hydrochloric acid) at $65^{\circ} \mathrm{C}$ for $25 \mathrm{~min}$ (Feulgen \& Rosenbech 1924).

The slides were examined with a Zeiss Axiolab microscope, and micrographs were obtained by using a MOTICAM 1000 digital camera. In this study, approximately 1 000 nuclei from cells showing various meiotic stages were used. Voucher specimens were deposited in the entomological collections of M. Lillo Institute (Tucumán, Argentina)

\section{RESULTS}

T. rubromarginata presents a male karyotype formula of $2 n=21(20+X)$. During meiotic stages, 10 bivalents and a univalent $\mathrm{X}$ chromosome were observed. Among the bivalent there is little difference in size. The bivalents showed few chromosomes decreasing in size. The size of the $\mathrm{X}$ chromosome is similar to the middle autosome pair, none of them have a primary constriction, thus being holokinetic.

In meiotic cells, from leptotene to diakinesis stages, the $\mathrm{X}$ chromosome shows positive heteropycnosis, and is usually located outside the autosomal chromatin mass (Fig. 1A). In the beginning of prophase I, leptotene/zygotene, it is possible to see the heteropycnotic body; it should be separate, but is located in the nucleus 

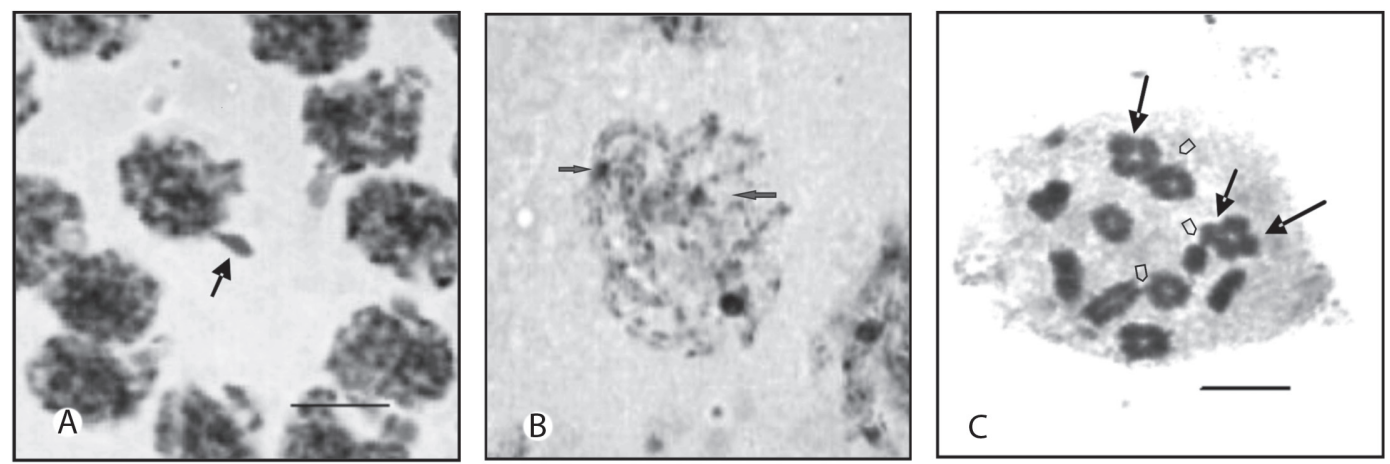

Fig. 1. Meiotic chromosomes of males of T. rubromarginata $2 \mathrm{n}=21(20 \mathrm{~A}+\mathrm{X} 0)$ : (A) Leptotene with $\mathrm{X}$ chromosome placed outside chromatine mass (arrow). (B) Pachitene: chromosome pairing. The arrow show a heteropycnotic body (Bar:10 $\mu \mathrm{m})$. (C) Diakinesis with chromosomes showing terminal and subterminal chiasmata (arrows). Arrowheads point signal an association between autosomes (Bar:10 $\mu \mathrm{m}$ ).

periphery. This can be seen until the end of pachytene (Fig. 1B). In pachytene the chromosomes are completely paired (Fig. 1B) and, in diplotene, they form 10 autosomal bivalents.

In diplotene/diakinesis some the autosomal bivalents shows telomeric associations (Fig. 1C). In addition, during diakinesis, the autosomal bivalents change their staining affinities so when they reach metaphase I, isopycnosis is highly noticeable. At this stage, the autosomal bivalents normally exhibit only one or two chiasmata located in different localization: terminal, subterminal or interstitial. Because the ring shape of the bivalents, the presence of two chiasmata is suggested (Fig. 1C).
The autosomes, as well as the $\mathrm{X}$ chromosome, segregate reductionally in anaphase I and divided equationally during the second division. Each homologue chromosome is oriented parallel to the achromatic spindle, thus the telomeric regions are active in meiosis I, while the $\mathrm{X}$ chromosome is observed as univalent (Fig. 2A). In telophase I, ten autosomes move towards each pole after reductional division while the $\mathrm{X}$ chromosome lags behind, but finally reach one of the poles (Fig. 2B).

Figure $2 \mathrm{C}$ represents a metaphase II nucleus, with 10 autosomes and the noticeable univalent $\mathrm{X}$ chromosome. In the second meiotic
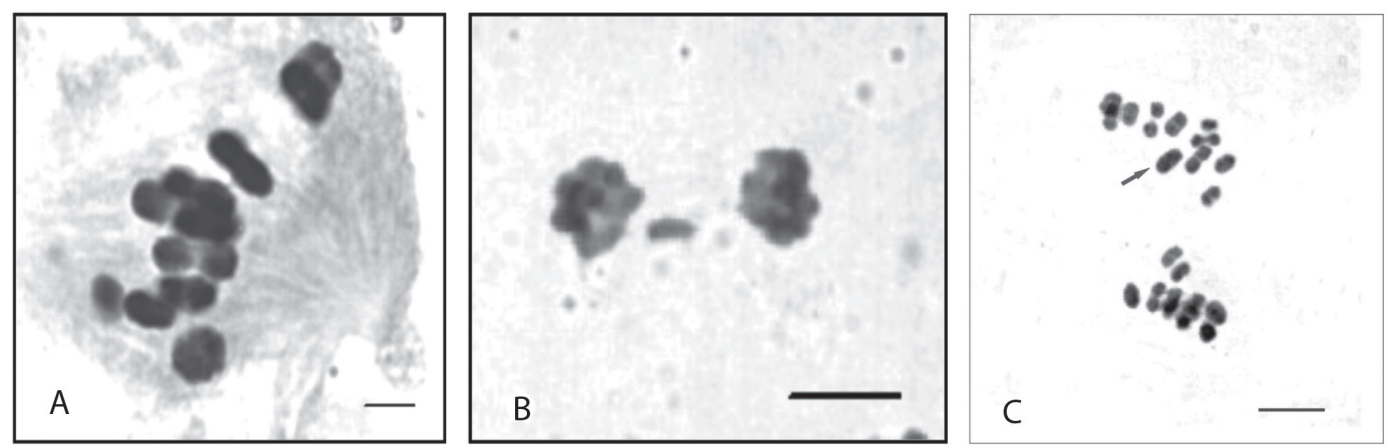

Fig. 2. Meiotic chromosomes of males of T. rubromarginata $2 \mathrm{n}=21(20 \mathrm{~A}+\mathrm{X} 0)$. (A) Metaphase I with bivalents oriented in parallel to the spindle. (B) Telophase I with a lagged chromosome (Bar:10 $\mu \mathrm{m}$ ). (C) Metaphase II (the arrow indicates the $\mathrm{X}$ chromosome) (Bar:10 $\mu \mathrm{m})$. 
division only one daughter cell received a sex chromosome in telophase II.

\section{DISCUSSION}

T. rubromarginata show in the male a diploid number of 21, with a sex mechanism of XO. This species displays holokinetic chromosomes, which are characteristic of Auchenorrhyncha as a whole (Halkka 1959).

Holokinetic chromosomes have been widely recorded both in vegetal and animal species (Mola \& Papeschi 2006). Within the Insecta, they are characteristic of many orders, including Hemiptera (Camacho et al. 1985, González-García et al. 1996). Some authors stated that holokinetic chromosomes represent a primitive character, while those having localized centromeres derived from them (Kiuta 1970, Sybenga 1981, 1992). It is generally assumed that holokinetic chromosomes facilitate karyotype evolution, by means of dissociations and fusion of chromosomes, sometimes leading to an increase in chromosome numbers (White 1973). This fact favors variability and adaptive capability of the species (Castro 1950, Kiuta 1970, Sybenga 1981, 1992). Jacobs (2004) considered fragmentation as the most important mechanism for the existence of high chromosome numbers in Dundocoris nodulicarius (Heteroptera).

During the segregation in the meiosis, holokinetic chromosomes can behave in different ways. In $T$. rubromarginata (anaphase I), the chromosomes have a parallel arrangement to the spindle fibers, and kinetic activity is restricted to the telomere regions. Based on such a behavior, holokinetic chromosomes of the heteropteran insect Dysdercus intermedius were as telokinetic (Motzko \& Ruthmann 1984). In T. rubromarginata the chromosome segregation takes place in anaphase I whereas the equational division occurs during anaphase II. This meiotic pattern is known to be characteristic of the most hemipteran groups. The observed behavior of the holokinetic chromosomes in this sharpshooter is opposite to the post-reductional meiosis with an equational separation in the first anaphase and a reductional segregation in the second anaphase mentioned for Aeshna (Odonata) (Mola 1995). Meiosis in organisms with monocentric chromosomes is always pre-reductional, where the first division is reductional with segregation of the homologous chromosomes and the second division is equational with segregation of the sister chromatids. Halkka (1959) considered the post-reductional meiosis is the most primitive type of meiosis.

Cytogenetically, the differences between the pre-reductional and post-reductional meiosis are characterized by the orientation of the bivalents (White 1973). In the former, the bivalents dispose parallel to the spindle fibers, while in the latter the chromosomes are oriented perpendicularly to the fibers, so sometimes it is called reversed meiosis. The resulting gametes from both kinds of division are indistinguishable (Mola \& Papeschi 2006).

Within the Auchenorrhyncha the chromosome number has a wide range, from $2 n=10$ to $2 \mathrm{n}=37$, as mentioned by Maryanska-Nadachowska et al. (2006). Our results, a male diploid number $21(20 \mathrm{~A}+\mathrm{X})$ in T. rubromarginata agree with the range of $2 \mathrm{n}=11$ and 24 mentioned for other Cicadellidae, being the most frequent number $2 \mathrm{n}=19,21$ or 23 (de Lello et al. 1982). Due to scarce cytogenetic analyses on Auchenorrhyncha, till now it was not possible to establish the modal number of chromosomes.

The sex determination mechanism XO:XX $\left(O^{\top}: O\right)$ seems to be the typical for Auchenorrhyncha (Halkka 1959, de Lello et al. 1982); Maryanska-Nadachowska et al. (2008) described a neo-XY system for a member of the Aphrophoridae (Cercopoidea).

Halkka (1964) determined the formation of one or two chiasmata in each bivalent in holokinetic chromosome. This pattern also seems to be typical of the Auchenorryncha. There are a few reports of holokinetic bivalents with more than two chiasmata (Tian \& Yuan 1997, Kuznetsova et al. 2003). This indicates that there are structural restrictions to chiasma formation in the holokinetic chromosomes. 
The given information represents the first contribution to cytogenetic aspect of proconines sharpshooters and particularly on Auchenorrhyncha species of economic relevance in Argentina.

\section{ACKNOWLEDGMENTS}

We are grateful to A.G. Papeschi for critically going through an early version of the ms and providing valuable suggestions. Also, to E. Frías for his technical assistance in collecting specimens.

\section{RESUMEN}

Los Cicadellidae son una de las familias mejor representadas en la región neotropical. La tribu Proconiini incluye a muchos de los insectos que se alimentan de xilema y la mayoría de los vectores de organismos fitopatógenos asociados con dicho tejido de conducción. La citogenética de los Proconiini es prácticamente inexplorada. Por lo tanto, se utilizaron técnicas citogenéticas convencionales para describir el cariotipo y la meiosis en los machos de Tapajosa rubromarginata Signoret. Este cicadélido presenta el complemento cromosómico diploide de $2 n=20 A+X 0$ en los machos. Los cromosomas no presentan constricción primaria, son holocinéticos, y la meiosis es pre-reduccional, muestra un comportamiento similar tanto en los cromosomas sexuales como en los autosómicos durante la anafase I. En ese estado, los cromosomas se orientan de manera paralela a las fibras del huso acromático con actividad cinética en los telómeros y segregan de manera reduccional en la fase I y ecuacional en la fase II de la meiosis.

Palabras Clave: Insecta, citogenética, Proconiini, cariotipo, cromosomas holocinéticos, cromosomas sexuales.

\section{REFERENCES}

Boring, A.M. 1907. A study of the spermatogenesis of 22 species of the Membracidae, Jassidae, Cercopidac and Fulgoridae with special reference to the behavior of the odd chromosome. J. Exp. Zool. 4: 469-514.

Camacho, J.P.M., J. Belda \& J. Cabrero. 1985. Meiotic behaviour of the holocentric chromosomes of Nezara viridula (Insecta, Heteroptera) analysed by C-banding and silver impregnation. Can. J. Genet. Cytol. 27: 490-497.

Castro, D. 1950. The structure of the centromere and its functioning. Genét. Ibér. 5: 1-33.
Costilla, M., H. Basco \& V. Osores. 1972. Primera cita para Tucumán del bicho llovedor de la caña Tapajosa rubromarginata (Signoret) (Homoptera - Cicadellidae), en cultivos de caña de azúcar. IDIA Suplemento 28: $126-129$.

de Azevedo-Filho, W.S. \& G.S. Carvalho. 2004. Guía para colecta e identificação de cigarrinhas em pomares de citros no Rio Grande do Sul. Edipucrs, Porto Alegre, Brazil.

de Lello, E., M. Menezes \& M.I.P. Coelho. 1982. Chromosomes studies on leafhoppers (Homoptera: Cicadellidae). Rev. Bras. Genet. 5: 69-93.

Feulgen, R. \& K.H. Rosenbeck. 1924. Mikroskopisch chemischer nachweiseiner nuclinsaure vom. Typus der thymonuclein same unde die darauf ber uhende elektiv farbung von zeikernen in mikroskopischen. Prapraten Zeitschr. Physik. Chem. 135: 203-248.

Freytag, P.H. \& M.J. Sharkey. 2002. A preliminary list of the leafhoppers (Homoptera: Cicadellidae) of Colombia. Biota Colombiana 3: 235-283.

Grandgirard, J., M.S. Hoddle, J.N. Petit, G.K. Roderick \& N. Davies. 2008. Engineering an invasion: classical biological control of the glassy-winged sharpshooter, Homalodisca vitripennis, by the egg parasitoid Gonatocerus ashmeadi in Tahiti and Moorea, French Polynesia. Biol. Invas. 10: 135-148.

González-García, J.M., C. Antonio, J.A. Suja \& J.S. Rufas. 1996. Meiosis in holocentric chromosomes: kinetic activity is randomly restricted to the chromatid ends of sex univalents in Graphosoma italicum (Heteroptera). Chromosome Res. 4: 124-132.

Halkka, O. 1957. A note on the chromosome numbers in the Homoptera Auchenorrhyncha. Hereditas 43: 465-466.

Halkka, O. 1959. Chromosomes Studies on the Hemiptera, Homoptera, Auchenorrhyncha. Ann. Acad. Sci. Fenn. Series A 43: 1-71.

Halkka, O. 1960a. The Structure of Bivalents in the Homoptera Auchenorrhyncha. Chromosome 11: 245-262.

Halkka, O. 1960b. Chromosomal Evolution in the Cicadellidae. Hereditas 46: 581-591.

Halkka, O. 1964. The Chromosomes of 17 nearctic Homoptera. Hereditas 52: 77-80.

Jacobs, D.H. 2004. The evolution of neo- $\mathrm{XY}_{1} \mathrm{Y}_{2}$ sex chromosome system by autosome sex chromosome fusion in Dundocoris nodulicarius Jacobs 
(Heteroptera: Aradidae: Carventinae). Chromosome Res. 12: 175-191.

Kiauta, B. 1970. Some remarks on the evolution of the centromere, based upon the distribution of centromere types in insects. Ent. Ber. 30: 71-75.

Kuznetsova, V.G., A. Maryanska-Nadachowska, C.T. Yang \& L.B. O'Brien. 1998. Karyotypes sex-chromosome system, and testis structure in Fulgoroidea (Auchenorrhyncha Homoptera, Insecta). Folia Biol. - Kraków 46: $33-40$.

Kuznetsova, V.G., A. Maryanska-Nadachowska \& S. Nokkala. 2003. A new approach to the Auchenorrhyncha (Hemiptera, Insecta) cytogenetics: chromosomes of the meadow spittlebug Philaenus spumarius (L.) examined using various chromosome banding techniques. Folia Biol. - Kraków 51: 33-40.

Kuznetsova, V.G., A. Maryanska-Nadachowska \& A. Emeljanov. 2009. A contribution to the karyosystematics of the planthopper families Dictyopharidae and Fulgoridae (Hemiptera: Auchenorrhyncha). Eur. J. Entomol. 106: 159-170.

Maryanska-Nadachowska, A., V.G. Kuznetsova, V.M. Gnezdilov \& S. Drosopoulos. 2006. Variability in the Karyotypes, testes and ovaries of planhoppers of the families Issidae, Caliscelidae, and Acanaloniidae (Hemiptera: Fulgoroidea). Eur. J. Entomol. 103: 505-513.

Maryanska-Nadachowska, A., V.G. Kuznetsova \& H. Abdul-Nour. 2008. A chromosomal study on a Lebanese spittlebug Philaenus arslani (Hemiptera: Auchenorryncha: Aphrophoridae). Insect Sci. 6: 227-232.

McKamey, S.H. 2002. Leafhoppers of the world data base: progress report, p.85. In Hoch, H., M. Asche, C. Homberg and P. Kessling (eds) $11^{\text {th }}$ International Auchenorrhyncha Congress, 5-9 August 2002, Potsdam/Berlin, Germany.

Mola, L.M. 1995. Post-reductional meiosis in Aeshna (Aeshnidae, Odonata) Hereditas 122: 47-55

Mola, L.M. \& A.G. Papeschi. 2006. Holokinetic chromosomes at a glance. BAG, J. Basic Appl. Genet. 17: 17-33.

Motzko, D. \& A. Ruthmann. 1984. Spindle membranes in mitosis and meiosis of the heteropteran insect Dysdercus intermedius. A study of the interrelationship of spindle architecture and the kinetic organization of chromosomes. Eur. J. Cell. Biol. 33: 205-216.

Nokkala, S., V.G. Kuznetsova, A. Maryanska-Nadachowska \& C. Nokkala. 2004. Holocentric chromosomes in meiosis. I. Restriction of the number of chiasmata in bivalents. Chromosome Res. 12: 733-739.

Paradell, S. 1995. Especies Argentinas de homópteros cicadélidos asociados al cultivo de maíz (Zea mays L.). Rev. Fac. de Agr. La Plata 71: 213-234.

Rakitov, R. \& C. Dietrich. 2001. Evolution and historical ecology of the proconiini sharpshooters, pp 139-140. In Proceeding Pierce's Disease Research Symposium. December 5-7, 2001, Coronado Island Marriot Resort, San Diego, California. Department of Food and Agriculture, Sacramento, California, USA.

Redak, R., A. Purcell, J. Spotti Lopez, M. Blua, R. Mizell \& P. Andersen. 2004. The biology of xylem fluidfeeding insect vectors of Xylella fastidiosa and their relations to disease epidemiology. Annu. Rev. Entomol. 49: 243-270.

Remes Lenicov, A.M., E.G. Virla \& M.E. Manca. 1998. Difusión de Tapajosa rubromarginata (Homoptera: Cicadellidae) sobre cultivos cerealeros de la Argentina. Rev. Soc. Entomol. Arg. 57: 18.

Remes Lenicov, A.M., S. Paradell \& E.G. Virla. 2004. Homoptera - Fulgoromorpha y Cicadomorpha, p. 330-342. In H.A. Cordo, G. Logarzo, K. Braun \& O.R. Di Iorio (eds.). Catálogo de Insectos fitófagos de la Argentina. Soc. Entomol. Argentina, Buenos Aires, Argentina.

Sybenga, J. 1981. Specialization in the behaviour of chromosomes on the meiotic spindle. Genetica 57: 143-151.

Sybenga, J. 1992. Cytogenetics in plant breeding. Monographs on theoretical and applied genetics. Springer, Berlin, Germany.

Takiya, D. \& D. Dimitriev. 2008. An interactive key to genera of the tribu Proconiini. (Downloaded: July 21, 2010, http://ctap.inhs.uiuc.edu/takiya/index.asp).

Tian, R. \& F. Yuan. 1997. Chromosomes in twenty-five species of Chinese membracids (Homoptera, Membracidae). Entom. Sin. 4: 150-158.

Virla, E.G., L. Cangemi \& G.A. Logarzo. 2007. Suitability of different host plants for nymphs of the sharpshooter Tapajosa rubromarginata (Hemiptera: Proconinii). Fla. Entomol. 90: 766-769.

White, M.J.D. 1973. Animal Cytology and Evolution. Cambridge University, London-New York.

Young, D.A. 1968. Taxonomic Study of the Cicadellinae (Homoptera: Cicadellidae) Part 1 Proconiini. Bull. U.S. Nat. Mus. 261: 1-287. 